\title{
More than tools? Making sense of the ongoing digitizations of higher education

\author{
Linda Castañeda ${ }^{{ }^{*}}$ and Neil Selwyn ${ }^{2}$
}

\author{
* Correspondence: lindacq@um.es \\ 'Grupo de Investigación de \\ Tecnología Educativa, \\ Departamento de Didáctica y \\ Organización Escolar, Facultad de \\ Educación, Universidad de Murcia, \\ Murcia, Spain \\ Full list of author information is \\ available at the end of the article
}

Keywords: Critical perspectives, Constructive criticism, Marketization, Neoliberalism, Pedagogy, Learning, Digital technologies

\section{Introduction}

In times of hype surrounding the 'Internet of Things', 'blockchain universities', 'learning analytics' and the like, this special issue of the International Journal of Educational Technology in Higher Education starts from a simple proposition - how might we develop critical perspectives and alternative visions of technology in higher education? Our initial call resulted in the six articles that you find attached. These were written from a diversity of perspectives, and therefore address a range of concerns and approaches. We have articles that consider the implications of neuroscience for understanding educational technology, phenomenological reinterpretations of the 'affordances' of technology, and the politics of 'big data' in higher education reform. Elsewhere is a reassessment of mobile learning, a critical exploration of the ideological underpinnings of national digital strategies, and pedagogical analysis of personalized and adaptive learning. Contributions have been made by authors across Europe working in psychology and the behavioural sciences, social sciences, education research, communications and the arts. We feel confident that this collection meets our initial intention of problematizing the claims and assumptions surrounding higher education in the digital age. This is an interesting and insightful set of arguments, offering a useful counterpoint to articles featured elsewhere in the journal.

While we are happy to have amassed this broad range of critical perspectives, we are not particularly surprised by the range of articles we received. The past 5 years has seen a sharp increase in scholars expressing critical views of education and technology. It is no longer an oddity to encounter challenging questions of the social, cultural, political and economic connotations of digital technology use in higher education. Nowadays, someone who problematizes the digitization of universities does not instantly draw accusations of being dystopian or simply out-of-touch. After decades of critical voices in education technology being simply ignored, or marginalized and maligned, it is now reassuring to be able to claim that there is nothing distinct about the articles that we present in this issue.

However, this is not to say that these articles do not deserve our close attention. As one might hope, this is a collection of interesting contributions that raises a range of important ideas. As such, we have decided not to waste our 'editorial'

(C) The Author(s) 2018 Open Access This article is distributed under the terms of the Creative Commons Attribution 4.0 International License (http://creativecommons.org/licenses/by/4.0/), which permits unrestricted use, distribution, and reproduction in any medium, provided you give appropriate credit to the original author(s) and the source, provide a link to the Creative Commons license, and indicate if changes were made. 
space simply by summarizing the contents of each article in turn. If you want an overview of what each author argues then feel free to browse the abstracts. Instead, we want to use this opportunity to reflect upon some of the broader conversations that these articles speak to. The following list is by no means comprehensive or necessarily representative - so feel free to identify alternatives. Nevertheless, let us outline a few over-arching issues and themes associated with these articles that we feel are definitely worth taking forward into subsequent discussions of higher education in the digital age.

\section{\#1. We need to talk about 'learning'}

Our first contention is straightforward - educational technology has yet to properly get to grips with matters of learning. On the one hand, digital technology use in higher education is a clear example of what Gert Biesta has termed 'learnification' - i.e. "the translation of everything there is to say about education in terms of learning and learners" (Biesta, 2009, p. 38). Thus this is an area that is often described as 'learning technology' or 'technology enhanced learning', and where technologies are framed in terms of their association with learning - i.e. 'learning management systems' and 'learning analytics'. This clearly limits the ways in which digital technologies are understood. As Biesta points out, there are many other aspects to education that stretch well beyond issues of learning. Framing digital technologies in terms of learning therefore obscures the socialization, subjectification and qualification purposes of education - as well as the political, economic and cultural aspects of the systems being used. As has been argued before, the most prevalent function of an 'learning management system' in universities is usually to support management rather than learning (Selwyn, 2016). Continually presenting educational technology through a learning lens renders our understandings abstracted from these other contexts of purpose.

On the other hand, while this is a field that likes to talk continuously about learning, it is striking how little of substance is said on the topic. Indeed, it is striking how little is known about the relationships between technology use and learning. Many discussions of education technology appear remarkably incurious about how learning might actually take place. Much work on technology-based learning appears unconnected to an explicit model of learning, and even those studies that do make reference to learning theories often do not fully follow this through. When learning theory is used there is an overreliance on 'pre-digital' theories of learning more suited to mid-twentieth century European classrooms than contemporary digital settings. Moreover, popular 'theories' of digital learning (such as connectivism and connected learning) are little more than flat descriptions of the logistics of online information seeking and communication. It is notable that many of the sharpest minds who once worked in the area of technology and learning are now moving into the areas of the 'learning sciences' and 'learning complexity' - recognizing that serious scholarship about learning is perhaps most fruitfully pursued outside of the field of educational technology.

In this sense, discussions of educational technology in higher education clearly need to be focused more sharply on working out, first what technology-based learning is, and then how learning is conceptualized in the design and deployment of technologies in universities. This will require sustained theorizing about the new biotechnological 
qualities of interconnected learning - especially in terms of how learning is moving beyond the boundaries of the brain, and what it means to learn when the prospect of accumulating transformed information in our brains is no longer sufficient (Clark, 2003). This will also require consideration of how established self-regulation mechanisms of learning are challenged by the use of technologies (Azevedo, 2009; Dabbagh \& Kitsantas, 2012), and what new forms of self-regulation and self-determined learning are now best supported by digital technologies. All told, there is much about 'learning' that needs to be re-thought and re-conceptualized.

\section{\#2. We need to talk about pedagogy}

Another surprising gap in discussions around digital technology and higher education is pedagogy. Looking back, it is notable how many studies published in the area of educational technology - even those having a great impact on subsequent literature - pay little consideration to underlying pedagogies and teaching models. Throughout most discussions of the development and implementation of technologies in higher education, there is little consideration of this fundamental element of educational action. Of course, this lack of acknowledgement of pedagogy does not mean that pedagogy is absent from these actions. On the contrary, pedagogy is inherently part of any educational technology use. Thus not explicitly addressing the pedagogical foundations of any instance of digital education makes it difficult to robustly question (let alone change) the ways in which the technology is being used to support learning.

This lack of pedagogic insight fundamentally limits what can be said about digital technology in an educational sense. At best, then, the pedagogies of technologybased education are framed as taken-for-granted and non-negotiable. Conversely, the supposedly 'urgent' issues that instead take up the time and attention of educational technologists (such as instrumental or contextual concerns over 'what works and why?'), cannot be fully understood or addressed without detailed knowledge of the pedagogical underpinnings of the technology use (Cobo, 2016). Talking about pedagogy implies being concerned about all aspects of any educational process be it intellectual, structural, or instrumental terms. Paying close attention to pedagogy allows us to understand that the educational use of technology is not a chaotic process with dynamics that are governed by chance. Instead, any educational use of technology is a complex process that is shaped, conditioned, and modified by a range of pedagogic actors and influences. All of these elements need to be known if we are to understand or improve the educational process (Decuypere \& Simons, 2016).

This raises a range of important questions about any forms of technology use in education. For example, what is the knowledge being developed, how do we understand how knowledge is generated and transformed (epistemology)? What are the most important processes to support people to learn (psychology)? What processes are set in motion in the processes of teaching and learning with the technology (didactics)? What role do the other pedagogic agents play and under what conditions do they operate? All of these are fundamental questions when it comes to understanding any educational process (Bartolomé, Castañeda, \& Adell, 2018). 
These might appear to be dry, boring details in comparison to the more exciting, creative, playful or even disruptive discussions of educational technology use. Yet sidestepping consideration of these important issues of pedagogic intent and epistemological outcomes clearly limits the scope of understanding what digital technologies are being used for in higher education, and with what consequences. The 'educational' element of educational technology is not simply common-sense or implicit. We need to develop visions that go beyond conceptualising digital technology as an instrument within instructional design (what might be called the classic object of interest within the field of educational technology) or a systemic conditioner of education as a specialized communication process (Aagaard, 2018). Instead, discussions about the pedagogic underpinnings of the technologies being used in university teaching and learning are muchneeded and long over-due.

\section{\#3. Acknowledging the 'human' aspects of digital technology use in education}

Thirdly, it is important for discussions of educational technology to extend beyond 'rational' aspects of the educational process (e.g. discussions of the informational, cognitive or neurological aspects of teaching and learning), and also give full consideration to education as a profoundly emotional and human process. It seems that there is a pronounced trend in many discussions of education and technology to discount (or even deny) affective aspects of the higher education experience. Much work continues to conceptualize education simply as a "collection of expertise and demonstrable abilities" (Zeide, 2017, p. 169). In contrast, cultural, affective, spiritual, emotional, and ecological aspects (Coeckelbergh, 2018; Earp \& Savulescu, 2018), are either assumed to be 'overcome' through hyper-rationalist forms of digital education, or else somehow controlled and re-programmable (Williamson, 2017). All of these perspectives work to denaturalize technology-based education and deny that is remains a human endeavour shaped by basic human characteristics.

Instead, more attention needs to be paid to the interplay between the use of digital technology and people's emotions, feelings and affect. This is essential if we are to fully engage with issues such as identity, responsibility and accountability, as well as the idea of digital technology use as a collective endeavour grounded in social relations. Moreover, it is also important to explore how the use of digital technologies in higher education settings profoundly shapes the emotions, moods and feelings of students and staff. The ways in which digital technologies are used in/for university plays an increasingly key part in the production of student and teacher subjectivities. As such, digital technologies do not simply support the transmission or exchange of information between staff and students. Instead, these technologies mould peoples' values, beliefs and behaviours. Conversely, it is also necessary to explore how these digital technologies are themselves shaped by people's emotions, moods and feelings - for example, exhaustion and excitement, boredom and flow, discomfort and relief. All of these issues highlight an area of change that is difficult to pin down - that is, how digital technologies are altering what it is to be human while at university. For example, how are digital technologies mitigating and/or exacerbating feelings of disconnection, distancing and what might be termed 'alienation'? How are people proving able to accommodate mismatches between human feelings and machine logics? 


\section{\#4. Digital technologies and the (hyper) individualisation of digital education}

Digital technologies are certainly proving to be a key vehicle for recasting higher education as an individualized activity. Indeed, some of the most prevalent forms of digital technology in higher education seem based on the implicit framing of individual students taking responsibility for decision-making with regards to their education, as well as dealing with the consequences of these decisions. We are told, for example, how digital education demands increased levels of selfdependence and entrepreneurial thinking on the part of students, with educational success dependent primarily on students' ability to self-direct their engagement with learning through various preferred forms of digital technology. In this sense, technology-based learning is increasingly positioned as an implicitly self-centred endeavour. Digital technology places students in personal formative cycles, and individual feedback loops. Individuals -students alongside lecturers and academics are expected to become industrious self-improvers, driven by external goals and striving to improve one's own performance.

Alongside this individualization of action is the reframing of higher education along less collective lines. Unencumbered by the need to learn and work with those in our immediate contexts, educational technologies are sold on the promise of making it easier to interact and learn with other people of our own choosing. One widely touted benefit of this is that the dispersed 'communities' of remote learners and academics established through digital technologies differ considerably in terms of social diversity, obligation, solidarity and social relations. All these changes may well have merit, yet need to be acknowledged more openly and vigorously discussed. One concern that readily springs to mind is how such shifts in emphasis sit with the traditional values and desires of 'public education' - i.e. education as a public good rather than private interest, and learning as a social rather than solipsistic undertaking. At best, these individualistic constructions of digital education could be said to be doing little to reflect issues of social justice, inequality or the notion of education as a collective public good. Depending on one's perspective such gaps may - or may not - constitute a problem, but these issues at least deserve more consideration within discussions of higher education and digital technology.

This raises a number of important questions. For example, to what extent does the idea of the self-responsibilized, self-determining learner advantage those individuals who are able to act in an agentic, self-motivated, empowered fashion - what Tressie McMillan Cottom (2016) has witheringly referred to as the ideal of the well-resourced 'roaming autodidact'? At best, then, it is likely that only privileged groups are able to act in this empowered fashion. As such, a number of scholars have begun to unpick the uneasy and often unconvincing assumption of the individual 'rational' learner operating within an efficient digital network (Blum-Ross \& Livingstone, 2016). Even, some of the objectives we mentioned before, regarding supposed emancipation of students, which could be understood as the empowerment of future professionals who manage their Personal Learning Environment (PLE) and which, as such, at least on theory are considered desirable within the competencies to be developed within the framework of higher education, actually are not developed almost at all (Prendes, Castañeda, Gutierrez, \& Roman, 2016). While digital education might work well for individuals, it is likely to work better for some individuals rather than others. 


\section{\#5. Digital technologies and the commercialization of higher education}

The use of digital technology in higher education is now a multi-billion dollar business which sees global technology corporations exerting increasing influence on the affairs of local universities. Thus, the wide-scale digitization of university teaching and learning raises a number of different 'commercialisations' of higher education that need to be better acknowledged. In particular, the market-led nature of higher education technology has connotations that reach well beyond from the simple provision of resources to university consumers. For example, much of the organization and administration of universities is now shaped by commercially-provided systems based around models developed for business and industry. The rise of 'content management systems', 'workload management systems', performance metrics and analytics could be seen to key elements in the steady corporatization of higher education - i.e. the restructuring and reorganization of universities to function and behave as if they were corporations.

Similarly, the commercial design of educational systems and software increasingly shapes the forms of teaching and learning that take place in universities. Regardless of the pedagogic intent of university educators, the software they use shapes what can and cannot be done in the classroom and lecture theatre. In this sense, it could be argued that "engineers, data scientists, programmers and algorithm designers are becoming today's most powerful teachers" (Williamson, 2017, n.p). This draws attention to the philosophies of pedagogy and learning that are 'baked into' the coded design of the software that universities purchase and use, alongside any corresponding consideration for equity, critique and other ideals that might be seen as traditional underpinning features of higher education.

It is also important to recognize the influence of the IT industry on policy and professional thinking about higher education. Indeed, in one way or another, the influences of the IT industry have been central to many of the recent technology-related educational reforms and innovations, sometimes in the supposedly innocuous form of "philanthropy" that helps in times of crisis. These includes seemingly innocuous ideas such as Digital Badges, Flipped Classroom, Twenty-First Century Skills, the Smart Campus and personalized learning. All of these ideas have been supported and sustained by the likes of Mozilla and Gates Foundations, Pearson, Cisco, Intel, Microsoft, Apple, and a host of smaller corporate names. Altogether, this industry activity continues to generate substantial pressure to reshape and redirect university education. As Kevin Carey (2012) observed, the most influential thought leaders in higher education are increasingly likely to be programmers, hackers and trillion-dollar Silicon Valley IT industry that has grown up around them.

\section{\#6. Digital technologies and the neoliberalisation of higher education}

Related to these issues of individualization and commercialisation is the implicit advancement of neoliberal values through the digitization of university processes and practices. While neoliberalism is often talked about in terms, there are a number of specific aspects that are clearly embodied in the forms of digitally-based education discussed in the special issue. In particular, it is striking that many forms of digital education seem aligned closely with the promotion of market mechanisms and free-market values. For example, the design of many forms of digital education appears to support 
rational market exchange as a dominant framework for organizing and regulating educational engagement. Moreover, digital technologies are increasingly used to support the overt monetization of education provision within commercial marketplaces. This is apparent in attempts to use online education to diversify higher education provision through alternate offerings such as the recently proposed $\$ 57,000$ per year 'Woolf University' - an online service which strives to function as 'Uber for students, Airbnb for academics' (THE, 2018).

It is also notable how digital technologies are also often used to promote the reconfiguration of education into a commodity state - i.e. framing education processes and practices into 'market forms' that have calculable and quantifiable value, and that are therefore exchangeable. One of the values implicit in many popular instances of digital education is the reconfiguration of educational practices and relations into forms that can be quantified and exchanged; governance practices are increasingly directed by market rationales, supported and fostered by principles of international ranking based competition (Diez, 2018). This can be seen in the increased use of online metrics, measurements and 'analytics', as well as the 'unbundling' of components of university learning in the form of micro-credentials, blockchain based programs and certifications, or digital portfolios.

Digital technologies are also implicit in the increased expansion of higher education into unfamiliar areas of society and social life, leading to what is celebrated as an 'always-on' state of potential educational engagement. Indeed, digital technologies are commonly used to support the expansion of university education into domestic, community and work settings. The idea of being able to engage with university work on a continuous 24/7 basis reframes the idea of 'the student' around a neoliberal ideal of the entrepreneurial consumer engaging with education on a flexible and self-motivated basis. While often promoted as making access to higher education more free and open, such forms of digital education clearly support ideas of higher education as a product that is consumed along economically rational lines.

\section{\#7. The need for constructive criticism of digital technologies and higher education}

All these previous points raise the need for usefully critical research and writing. As the articles in this special issue show, being critical of digital technology in higher education does not entail a blanket dismissal of all things technological. It is all too easy for people to slip into dystopian fears of universities being ruined beyond repair by developments in digital education. Moreover, academic critique of digital higher education should not be conducted with a 'moralizing undertone' (Massumi, 2015, p. 14). As Banks and Deuze (2009, p. 425) warn, critical academic observers are not somehow "lifting the veil from the eyes of otherwise hapless participants". Students, staff and institutions who are involved in the forms of digital education described above are certainly not 'dupes' whose failings are only apparent to the outside academic observer. Thus, critical accounts of higher education and technology should strive to offer different - rather than better - perspectives on the topic. Critical scholars should not be dismissive or discounting of other approaches. As Rita Felski (2015) reminds us, just because other work is not critical does not mean that it is uncritical. Thus, critical studies need to be conducted in a generous, open-minded spirit if they are to find a place in the general educational technology firmament. 
Similarly, it is important to remember that the underlying aim of taking a critical approach is the desire to make a difference. To be more specific, the aim of critical scholarship should be to make digital higher education 'better' than it currently is. Taking a critical approach toward digital technology use in universities is a constructive rather than destructive exercise. Critical studies should set out to critique rather than criticize - the aim here is to "make meaning out of things, not find fault in them" (Watson, 2016, n.p). Thus, ideally critical studies of education and technology will result in the proposition of alternate uses of technology. The ultimate aim of taking a critical approach to educational technology in higher education is therefore to turn critique and insight into the production of alternative strategies. In pursuing this aim, it is important to remember that any critique is never "the final word" on a matter (Konstantinou, 2016, n.p). Instead, this is work that is intended as the starting point of a conversation, and the beginning of renewed efforts to look for better ways of doing things.

\section{Conclusions}

While these discussion points cover a lot of ground, this is by no means an exhaustive list. If given another 5000 words to play with, then we might easily come up with seven different issues. Each author could undoubtedly come up with a further seven issues specific to their own article. The key point here is that there are plenty of important conversations that need to take place about digital technology and higher education beyond the presumption that technology is an instrumental issue that is neutrally implemented. As each of the articles in this special issue illustrate, the need for critical questions to be asked of higher education and digital technology is more pressing than ever.

Perhaps the key sensibility underlying all these issues is that the digitization of higher education is something that needs to be framed in problematic - rather than celebratory - terms. In making this point we are not arguing that digital technologies are necessarily bad. Rather we are suggesting that digital technologies need to be seen as problematic. This requires an ongoing suspicion and scepticism (rather than cynicism) toward seemingly 'ubiquitous' technologies that are all too easy to take for-granted as they recede into the background of everyday life. This also involves an active commitment to 'thinking otherwise' about how these technologies might be better implemented across higher education settings. As Michel Foucault (cited in Dreyfus \& Rabinow, 1982, pp. 231-232) put it:

"My point is not that everything is bad, but that everything is dangerous, which is not exactly the same as bad. If everything is dangerous, then we always have something to do. So my position leads not to apathy but to a hyper-and pessimistic activism. I think that the ethico-political choice we have to make every day is to determine which is the main danger."

These are sentiments that one might not associate immediately with discussions of digital technology use in higher education. Indeed, most people are a long way from framing digital technology and universities in ethico-political terms, let alone as cause for vigilance and activism. Yet these are sentiments and concerns that clearly need to 
be more forcibly acknowledged as we move beyond instrumental questions of 'what works?' and 'how can technology fix education?'. Clearly the role of digital technology within the fast-changing machinations of higher education is complex. The six articles in this special issue go some way to suggesting directions for future discussions and debates. We therefore look forward to seeing these conversations developing in the pages of this journal for many years to come. These are not problems that are going to be resolved quickly.

Authors' contributions

Both authors read and approved the final manuscript.

\section{Competing interests}

The authors declare they do have no competing interests.

\section{Publisher's Note}

Springer Nature remains neutral with regard to jurisdictional claims in published maps and institutional affiliations.

\section{Author details}

${ }^{1} G r u p o$ de Investigación de Tecnología Educativa, Departamento de Didáctica y Organización Escolar, Facultad de Educación, Universidad de Murcia, Murcia, Spain. ${ }^{2}$ Monash University, Clayton, Australia.

Received: 24 April 2018 Accepted: 2 May 2018

Published online: 14 May 2018

\section{References}

Aagaard, J. (2018). Magnetic and multistable: Reinterpreting the affordances of educational technology. International Journal of Educational Technology in Higher Education, 15, 4. https://doi.org/10.1186/s41239-017-0088-4.

Azevedo, R. (2009). Theoretical, conceptual, methodological, and instructional issues in research on metacognition and self-regulated learning: A discussion. Metacognition and Learning, 4(1), 87-95. https://doi.org/10.1007/s11409-0099035-7.

Banks, J., \& Deuze, M. (2009). Co-creative labour. International Journal of Cultural Studies, 12(5), 419-431. https://doi.org/10. $1177 / 1367877909337862$.

Bartolomé, A., Castañeda, L., \& Adell, J. (2018). Personalisation in educational technology: The absence of underlying pedagogies. International Journal of Educational Technology in Higher Education, 15(1), 14. https://doi.org/10.1186/s41239018-0095-0.

Biesta, G. (2009). Good education in an age of measurement: On the need to reconnect with the question of purpose in education. Educational Assessment, Evaluation and Accountability, 21(1), 33-46. https://doi.org/10.1007/s11092008-9064-9.

Blum-Ross, A., \& Livingstone, S. (2016). From youth voice to young entrepreneurs: The individualization of digital media and learning. Journal of Digital and Media Literacy, 4(1/2) http://www.jodml.org.

Carey, K. (2012). The siege of academe. Washington: https://washingtonmonthly.com/magazine/septoct-2012/the-siege-ofacademe/.

Clark, A. (2003). Natural-born cyborgs: Minds, technologies, and the future of human intelligence. Oxford University Press.

Cobo, C. (2016). La Innovación Pendiente. In Colección Fundación Ceibal/ debate Retrieved from http://innovacionpendiente. $\mathrm{com} /$.

Coeckelbergh, M. (2018). Technology and the good society: A polemical essay on social ontology, political principles, and responsibility for technology. Technology in Society, 52, 4-9. https://doi.org/10.1016/j.techsoc.2016.12.002.

Cottom, T. (2016). Black cyberfeminism: Ways forward for classification situations, intersectionality and digital sociology. In J. Daniels, T. Cottom, \& K. Gregory (Eds.), Digital sociologies, (pp. 211-230). Bristol: Policy Press.

Dabbagh, N., \& Kitsantas, A. (2012). Personal learning environments, social media, and self-regulated learning: A natural formula for connecting formal and informal learning. The Internet and Higher Education, 15(1), 3-8. https://doi.org/10. 1016/j.iheduc.2011.06.002.

Decuypere, M., \& Simons, M. (2016). Relational thinking in education: Topology, sociomaterial studies, and figures. Pedagogy, Culture \& Society, 24(3), 371-386. https://doi.org/10.1080/14681366.2016.1166150.

Diez, E. (2018). Neoliberalismo educativo. Madrid: Octaedro.

Dreyfus, H., \& Rabinow, P. (1982). Michel Foucault: Beyond structuralism and hermeneutics. Brighton: Harvester.

Earp, B. D., \& Savulescu, J. (2018). Love drugs: Why scientists should study the effects of pharmaceuticals on human romantic relationships. Technology in Society, 52, 10-16. https://doi.org/10.1016/j.techsoc.2017.02.001.

Felski, R. (2015). The limits of critique. Chicago: Chicago University Press.

Konstantinou, L. (2016). The hangman of critique. Los Angeles Review of Books https://lareviewofbooks.org/article/thehangman-of-critique/.

Massumi, B. (2015). Politics of affect. Cambridge: Wiley.

Prendes, M. P., Castañeda, L., Gutierrez, I., \& Roman, M. (2016). Still far from personal learning: Key aspects and emergent topics about how future professionals' PLEs are. Digital Education Review, 29, 15-30.

Selwyn, N. (2016). Minding our language - Why education and technology is full of bullshit ... and what might be done about it. Learning, Media and Technology, 41(3), 437-443. https://doi.org/10.1080/17439884.2015.1012523. 
THE [Times Higher Education] (2018). Oxford academics launch world's first 'blockchain university'. Times Higher Education www.timeshighereducation.com/news/oxford-academics-launch-worlds-first-blockchain-university.

Watson, S. (2016). How Virginia Heffernan is reinventing tech criticism. Columbia Journalism Review http://www.cjr.org/tow_ center/tech_criticism_virginia_heffernan.php.

Williamson, B. (2017). Learning machines. https://codeactsineducation.wordpress.com/2017/11/09/learning-machines/

Zeide, E. (2017). The structural consequences of big data-driven education (SSRN scholarly paper no. ID 2991794). Rochester: Social Science Research Network Retrieved from https://papers.ssrn.com/abstract=2991794.

Submit your manuscript to a SpringerOpen ${ }^{0}$ journal and benefit from:

- Convenient online submission

- Rigorous peer review

- Open access: articles freely available online

- High visibility within the field

- Retaining the copyright to your article

Submit your next manuscript at $\boldsymbol{\nabla}$ springeropen.com 